\title{
A new deep-sea genus of the family Artotrogidae (Copepoda: Siphonostomatoida) from the Gorda Ridge (North Pacific Ocean)
}

\author{
Viatcheslav N. Ivanenko ${ }^{1}$, Eugenia Bandera ${ }^{2}$, Mercedes Conradi² \\ ${ }^{I}$ Department of Invertebrate Zoology, Biological Faculty, Lomonosov Moscow State University, \\ Moscow119992, Russia.E-mail: ivanenko@mail.bio.msu.ru \\ ${ }^{2}$ Laboratorio de Biología Marina, Departamento de Zoología, Facultad de Biología. Universidad \\ de Sevilla. Reina Mercedes 6, 41012 - Sevilla, Spain.
}

ABSTRACT: Adult female and male of Artogordion ridgeus gen. et sp.n. (Copepoda: Siphonostomatoida) of the family Artotrogidae Brady, 1880 are described from the Gorda Ridge of the North Pacific Ocean. The copepods were found at depths of 2656-2701 m on the margin of a hydrothermal vent field among invertebrates colonizing wood blocks deployed for two years. The new genus differs from other genera of Artotrogidae by a number of primitive features and is close to Myzopontius Giesbrecht, 1895, Sestropontius Giesbrecht, 1899 and Neopontius T. Scott, 1898. It is distinguished from them by segmental fusion pattern of the antennule, the armature of the antennary exopod and the maxillule, and the length and armature of the caudal ramus. This is the second artotrogid to be found in deep water after the discovery of Abyssopontius altus Stock, 1985 in the Indian Ocean.

How to cite this article: Ivanenko V.N., Bandera E., Conradi M. 2018. A new deep-sea genus of the family Artotrogidae (Copepoda: Siphonostomatoida) from the Gorda Ridge (North Pacific Ocean) // Invert. Zool. Vol.15. No.3. P.249-266. doi: 10.15298/invertzool.15.3.04

KEY WORDS: Artotrogidae, Siphonostomatoida, Copepoda, North Pacific Ocean, Gorda Ridge, deep sea, hydrothermal vent, taxonomy.

\section{Новый глубоководный род семейства Artotrogidae (Copepoda: Siphonostomatoida) с хребта Горда (северная часть Тихого океана)}

\section{В.Н. Иваненко ${ }^{1}$, Е. Бандера², М. Конради²}

\footnotetext{
${ }^{1}$ Кафедра зоологии беспозвоночных, Биологический факультет, Московский государственный университет им. М.В. Ломоносова, Москва 119992, Россия. E-mail: ivanenko@mail. bio.msu.ru

${ }^{2}$ Laboratorio de Biología Marina, Departamento de Zoología, Facultad de Biología. Universidad de Sevilla. Reina Mercedes 6, 41012 - Sevilla, Spain.
}

РЕЗЮМЕ: Половозрелая самка и самец Artogordion ridgeus gen. et sp.n. (Copepoda: Siphonostomatoida), относящиеся к новому виду и роду семейства Artotrogidae Brady, 1880 , найдены на хребте Горда, расположенном в северной части Тихого океана. Веслоногие ракообразные обнаружены среди беспозвоночных, заселивших древесные блоки, размещенные на два года у края гидротермального поля на глубине 2656- 
2701 м. Новый род отличается от других родов семейства Artotrogidae рядом примитивных признаков и близок к родам Myzopontius Giesbrecht, 1895, Sestropontius Giesbrecht, 1899 и Neopontius T. Scott, 1898. Он отличается от этих родов характером слияния члеников антеннул, вооружением экзопода антенн и максиллул, а также длиной и вооружением каудальных ветвей. A. ridgeus sp.n. gen.n. это второй глубоководный вид артотрогид после находки в Индийском океане Abyssopontius altus Stock, 1985.

Как цитировать эту статью: Ivanenko V.N., Bandera E., Conradi M. 2018. A new deepsea genus of the family Artotrogidae (Copepoda: Siphonostomatoida) from the Gorda Ridge (North Pacific Ocean) // Invert. Zool. Vol.15. No.3. P.249-266. doi: 10.15298/ invertzool.15.3.04

КЛЮЧЕВЫЕ СЛОВА: Artotrogidae, Siphonostomatoida, Copepoda, северная часть Тихого океана, хребет Горда, глубоководье, гидротермальные источники, таксономия.

\section{Introduction}

Siphonostomatoida is an abundant and highly diverse order of copepod crustaceans living in symbiosis with a wide range of hosts including diverse invertebrates (coelenterates, crustaceans, echinoderms, sponges, etc.) and vertebrates (fish and cetaceans) (Boxshall, Halsey, 2004). Some of the deep-sea siphonostomatoid copepods are found free-living on bacterial mats at hydrothermal sites or in plankton (Humes, 1988a; Ivanenko, 1998; Gollner et al., 2010; Ivanenko et al., 2011). The diversity of siphonostomatoid copepods, their distribution and host specificity, especially deep-waters, are poorly investigated. Among the deep-water siphonostomatoid copepods that are relatively better studied are those living in hydrothermal communities (Dirivultidae Humes, Dojiri, 1980 and Ecbathyriontidae Humes, 1987) or on deepwater fishes (Hatschekiidae Kabata, 1979; Hyponeoidae Heegaard, 1962; Lernaeopodidae Milne Edwards, 1840; Pennellidae Burmeister, 1835; Sphyriidae Wilson, 1919) (Boxshall, 1998; Ivanenko et al., 2007, 2011; Gollner et al., 2010; Ivanenko, Arbizu, 2018). Knowledge of siphonostomatoids from other environments deeper than $1000 \mathrm{~m}$ is limited to a few descriptions of new species representing Artotrogidae Brady, 1880; Asterocheridae Giesbrecht, 1899; Brychiopontiidae Humes, 1974; Megapontiidae Heptner, 1968 and Nicothoidae Dana, 1852 found in symbiosis with crustaceans, holothurians or without indication of hosts (Stock, 1985; Humes, 1974, 1987, 1988a,b; Ivanenko, Defaye, 2004; Mahatma et al., 2008; Kakui, 2016).

A new species and genus of the family Ecbathyriontidae was recently found among invertebrates colonizing wood blocks deployed on the margin of a hydrothermal vent field of the Gorda Ridge (Ivanenko, Arbizu, 2018). This paper describes another new species and genus belonging to the family Artotrogidae found on the wood blocks. This is the second report of an artotrogid copepod in deep water after Abyssopontius altus Stock, 1985 found in the Indian Ocean at a depth of 5300 m (Stock, 1985).

\section{Material and Methods}

The copepods were found in sediment sieved from sea water in recovery boxes of wood blocks deployed for two years on the northern Gorda Ridge (ROV Tiburon, R/V Western Flyer). The boxes were recovered on August 31st and September 3rd of 2004 (DSV Alvin, dive 4044 and 4046, respectively, R/V Atlantis) (Voight, 2005, 2007).

The copepods were preserved in $8 \%$ buffered formalin, rinsed in distilled water and transferred to glycerin, dissected under a Leica MZ12 microscope and studied applying the 'hanging drop method' with a Leica DMR compound microscope using bright-field and differential 
interference contrast optics (Ivanenko, Defaye, 2004). Drawings were made with a camera lucida mounted on the microscope. For longterm preservation the dissected copepods were mounted on slides in glycerol, sealed with paraffin and deposited in the collection of the Field Museum of Natural History, Chicago, USA (FMNH).

\section{Taxonomic account}

Siphonostomatoida Burmeister, 1835

Artotrogidae Brady, 1880 Artogordion gen.n.

DIAGNOSIS. Female. Body cyclopiform unmodified. Urosome 5-segmented. Genital double-somite longer than wide, anterior half with lateral expansions; gonopores located dorso-laterally on lateral expansions, copulatory pores located ventral to gonopores. Rostrum small, slightly pointed ventral prominence. Caudal ramus elongate, with 7 setae. Oral cone short. Antennule 14-segmented in female with aesthetasc on apical segment; 1st segment with 1 long and 1 minute setae; 9th segment with 8 setae. Antennule 19-segmented in male with 11 aesthetascs. Antenna with 1-segmented exopod bearing 3 setae and 2-segmented endopod, distal segment elongate with 3 long setae, two terminal and one subterminal. Mandible without palp, with stylet-like gnathobase. Maxillule bilobed; inner lobe and outer articulating lobe with 5 (including 2 small) and 3 setal elements, respectively. Maxilla 2-segmented, second segment slender and recurved. Maxilliped 5-segmented with long terminal claw. Legs 1-4 with 3 -segmented rami; armature formula of legs shown in Table 1. Leg 5 articulating segment ventral, with 1 adjacent seta; free segment bearing 3 setae and 2 tooth-like processes in female and 3 setae and two spines in male. Leg 6 represented by 1 long seta and 1 small spiniform element in female and 2 long setae and 1 spiniform element in male.

TYPE SPECIES. Artogordion ridgeus sp.n. is the type species by original designation.

ETYMOLOGY. The generic name Artogordion is derived from combination of "Arto" referring to the family Artotrogidae and the word "Gorda" referring to the Gorda Ridge. The gender is masculine.

\section{Artogordion ridgeus sp.n. \\ Fig. 1-10.}

TYPE-MATERIAL. Holotype female (FMNH-INV 15515), 42045.258'N 126042. 572'W, depth $2701 \mathrm{~m}$, Alvin Dive 4044, 31/08/ 2004, near margin of the Sea Cliff (GR-14) hydrothermal field; allotype male (FMNH-INV 12992), $47^{\circ} 47.085 \mathrm{~N} 127^{\circ} 41.478 \mathrm{~W}$, depth 2656 m, Alvin Dive 4046, 3/09/2004, near the Wuzza Bear Mount; Gorda Ridge, North Pacific Ocean. DESCRIPTION.

FEMALE. Body (Fig. 1A, B) cyclopiform, total length, excluding caudal setae, $2.11 \mathrm{~mm}$,

Table 1. Formula for the armature of legs 1-4 of female of Artogordion ridgeus gen. et sp.n. Roman numerals indicate spines, Arabic numerals, setae.

Таблица 1. Формула вооружения плавательных ног 1-4 самки Artogordion ridgeus gen. et sp.n. Римские цифры обозначают шипы, арабские цифры — щетинки.

\begin{tabular}{lllll}
\hline & Coxa & Basis & Exopod & Endopod \\
\hline Leg 1 & $0-1$ & $1-\mathrm{I}$ & I-1; I-1; II,I,5 & $0-1 ; 0-2 ; 1,2,3$ \\
Leg 2 & $0-1$ & $1-0$ & $\begin{array}{l}\text { I-1; I-1; III,I,5 } \\
\text { or III,I,4 }\end{array}$ & $0-1 ; 0-2 ; 1,1+\mathrm{I}, 3$ \\
Leg 3 & $0-1$ & $1-0$ & I-1; I-1; III,I,5 & $0-1 ; 0-2 ; 1,1+\mathrm{I}, 3$ \\
Leg 4 & $0-1$ & $1-0$ & I-1; I-1; III,I,5 & $0-1 ; 0-2 ; 1,1+\mathrm{I}, 2$ \\
\hline
\end{tabular}




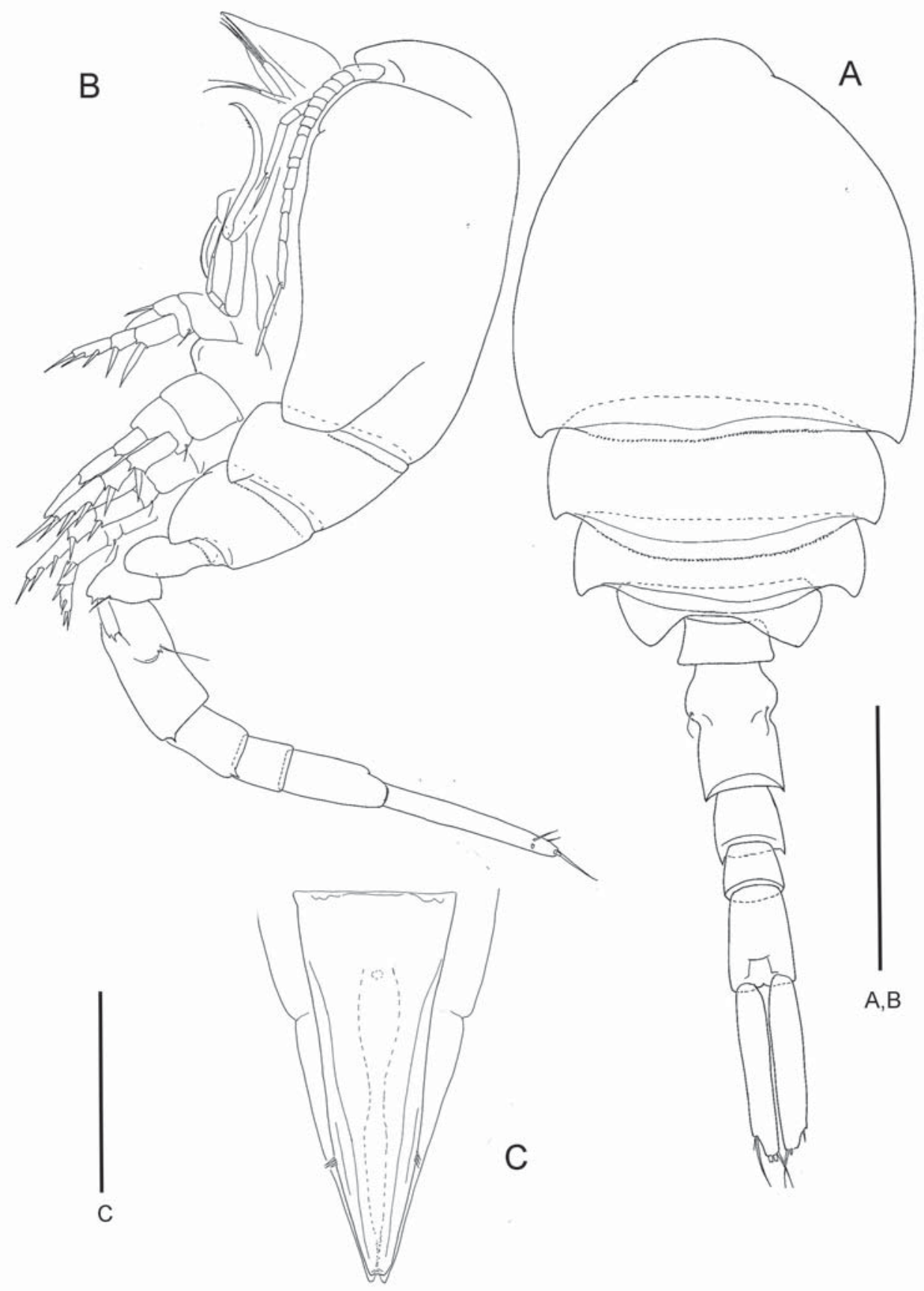

Fig. 1. Artogordion ridgeus sp.n. gen.n., holotype female. A - habitus, dorsal; B - habitus, lateral; C oral cone, anterior. Scale bars: A, B $-0.5 \mathrm{~mm} ; \mathrm{C}-0.3 \mathrm{~mm}$.

Pис.1. Artogordion ridgeus sp.n. gen.n., голотип, самка. А - общий вид сверху; В - общий вид сбоку; $\mathrm{C}-$ ротовой конус, вид спереди. Масштабный отрезок: $\mathrm{A}, \mathrm{B}-0,5$ мм; $\mathrm{C}-0,3$ мм. 


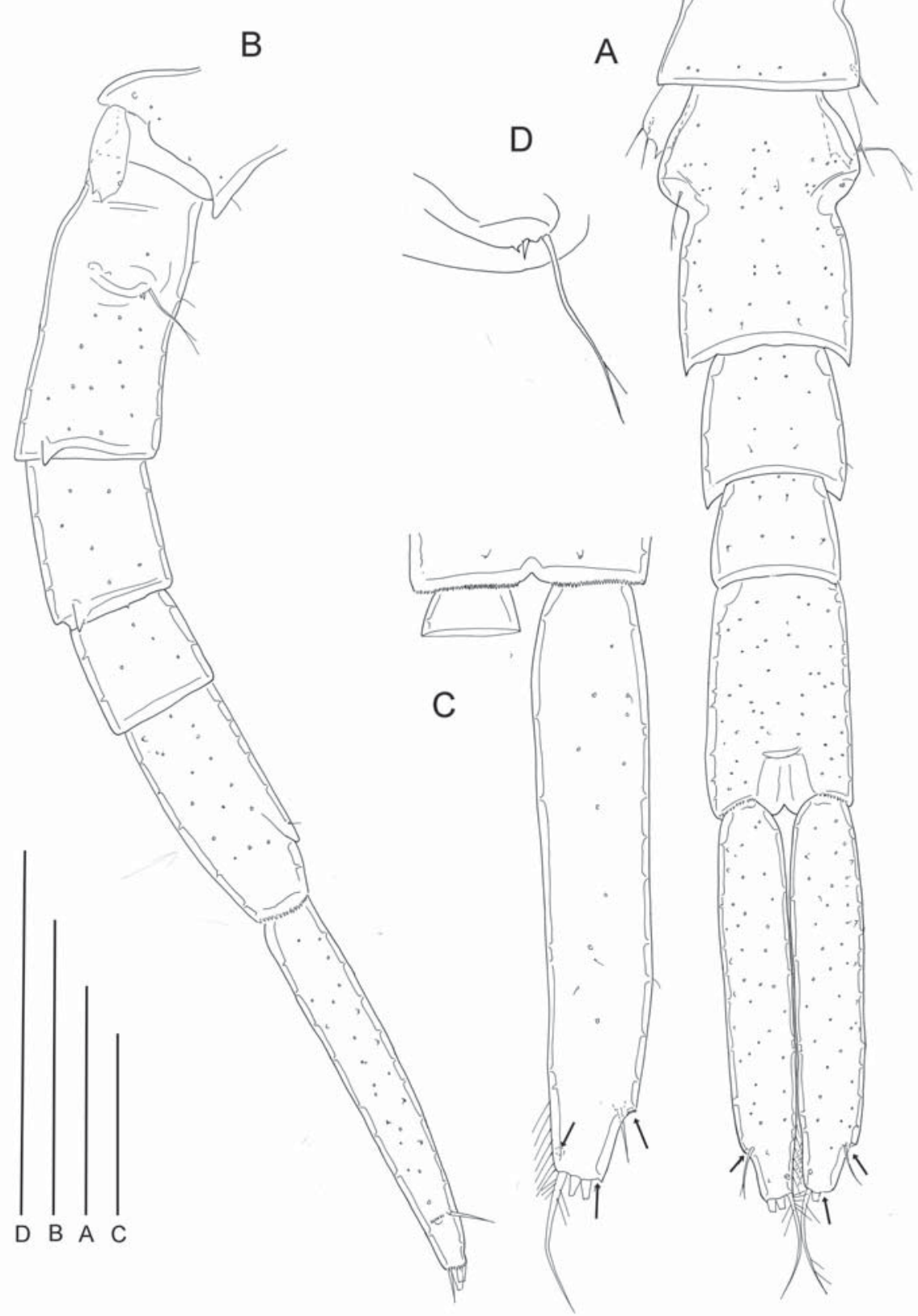

Fig. 2. Artogordion ridgeus gen. et sp.n., holotype female. A - urosome and caudal rami, dorsal; B urosome and caudal ramus, lateral; $\mathrm{C}$ - right caudal ramus, dorsal; D - left leg 6, lateral. Missing setae arrowed. Scale bars: A $-0.2 \mathrm{~mm}$; B-D $-0.3 \mathrm{~mm}$.

Рис. 2. Artogordion ridgeus gen. et sp.n., голотип, самка. А - уросома и каудальные ветви, вид сверху; $\mathrm{B}$ - уросома и каудальные ветви, вид сбоку; C — правая каудальная ветвь, вид сверху; D — левая нога 6, вид сбоку. Положение утраченных щетинок отмечено стрелками. Масштабный отрезок: A 0,2 мм; B-D - 0,3 мм. 
greatest width $0.75 \mathrm{~mm}$, greatest dorsovental thickness $0.46 \mathrm{~mm}$ based on one specimen in glycerol. Ratio of length to width of prosome 1.5:1. Ratio of length of prosome to that of urosome 1.08:1. Epimeral areas of cephalothorax and pedigerous somites $2-4$ pointed without lateral projections. Somite bearing leg 5 (Fig. 2A) $115 \times 440 \mu \mathrm{m}$. Prosome 4-segmented, ovoid, ornamented with sensilla and pores (not shown); anterior half consisting of cephalothorax followed by 3 free somites bearing swimming legs 2-4. Urosome (Figs 2A, B, 3A) 5-segmented, consisting of fifth pedigerous somite, genital double-somite, and 3 articulated abdominal somites, all segments ornamented with sensilla and pores. First somite of urosome trapezoidal in dorsal view. Genital double-somite 1.5 times longer than wide with lateral rounded expansions in anterior half; gonopores located dorsolaterally on anterior half of lateral expansions, copulatory pores ventral to gonopores. Anal opening (Fig. 2A) on dorsal side.

Rostrum a small, slightly pointed ventral process.

Oral cone (Fig. 1B, C) $590 \mu \mathrm{m}$ long, pointed distal part formed by labrum and labium ornamented with two rows of small setules laterally.

Caudal ramus (Fig. 2A-C) 5.8 times longer than wide, with 7 setae and ornamented with scales and setules. Precise arrangement of setae at distal end of caudal ramus not easy to interpret; most of them naked but intermost $250 \mu \mathrm{m}$ and plumose; dorsal small, $90 \mu \mathrm{m}$, and naked.

Antennule (Fig. 4A-D) 14-segmented; segmental fusion pattern and setation as follows (Roman numerals indicate ancestral segments number, following Huys, Boxshall, 1991 and Ivanenko, 1999; a - aesthetasc, s - seta(e), sp — spiniform element): 1(I)-2s; 2(II)-2s; 3(III)2s; 4(IV)-2s; 5(V)-2s; 6(VI)-2s; 7(VII)-2s; 8(VIII)-1s; 9(IX-XIII)-7s+sp; 10(XIV)-1s+sp; 11(XV-XVI)-2s; 12(XVII-XVIII)-2s; 13 (XIX-XX)-2s; 14(XXI-XXVIII)-15s+a. Segment 1 with 1 long and 1 minute setae. Segments 11 and 12 subdivided (Fig. 4A, D). Segment 14 with 2 minute and 3 fused at base setae shown partly (Fig. 4C). Lengths of segments measured along posterior margin, $175,85,70,70,65,55$,
$45,60,115,60,105,125,130$, and $215 \mu \mathrm{m}$, respectively. All setae naked.

Antenna (Fig. 3B) $580 \mu \mathrm{m}$ long excluding terminal setae, with small coxa without ornamentation, elongate basis with one setule on inner margin. Exopod 1-segmented, with 3 smooth setae of different lengths: 1 terminal, and 2 lateral. Endopod 2-segmented; first segment $120 \mu \mathrm{m}$ long, unarmed, shorter than basis, with setules on outer margin; segment 2 elongated, $270 \mu \mathrm{m}$ long, with short setules on outer margin, armed with 2 long plumose and 1 small terminal seta, 185 and $220 \mu \mathrm{m}$ long, and 1 subterminal smooth seta $(175 \mu \mathrm{m})$.

Mandible (Fig. 5A) elongate and stylet -like element formed by coxa and gnathobase (Ferrari, Ivanenko, 2008), $575 \mu \mathrm{m}$ long terminally armed with small denticles. Without palp.

Maxillule (Fig. 5B) bilobed; inner lobe, 255 $\mu \mathrm{m}$ long, with row of setules on inner margin and 5 terminal setae: 2 long ( 250 and $260 \mu \mathrm{m})$ and robust with spinules, 1 long $(190 \mu \mathrm{m})$ and naked, 1 very short $(40 \mu \mathrm{m})$ and 1 minute $(15$ $\mu \mathrm{m})$; articulating outer lobe $(170 \mu \mathrm{m})$ shorter than inner with 3 terminal setae: 2 long $(305,275$ $\mu \mathrm{m}$, joined at their base), ornamented with setules and spinules, and 1 short $(45 \mu \mathrm{m})$ and naked.

Maxilla (Fig. 5C) 2-segmented, but with partial transverse indentation on syncoxa possibly marking plane of praecoxa-coxa fusion. Coxal part unarmed and devoid of ornamentation. Basis claw-like recurved at end, $675 \mu \mathrm{m}$ long, with two rows of spinules in distal half and 1 needle-like spine near middle of segment.

Maxilliped (Fig. 5D) 5-segmented; comprising short syncoxa with 1 inner smooth seta; long basis with short inner seta and one row of setules on outer margin. Endopod 3-segmented: first endopodal segment bearing 3 smooth setae; second segment with subterminal plumose seta; third segment with 1 terminal seta and long and slender claw-like element $(330 \mu \mathrm{m})$.

Swimming legs 1-4 (Figs 6A-B, 7A-D) with 3-segmented rami. Formula for armature of legs 1-4 in Table 1. Leg 1: outer spine of first exopodal segment slightly longer than that of second segment. Leg 4: most distal inner seta of exopodal segment 3 shorter than other setae of 

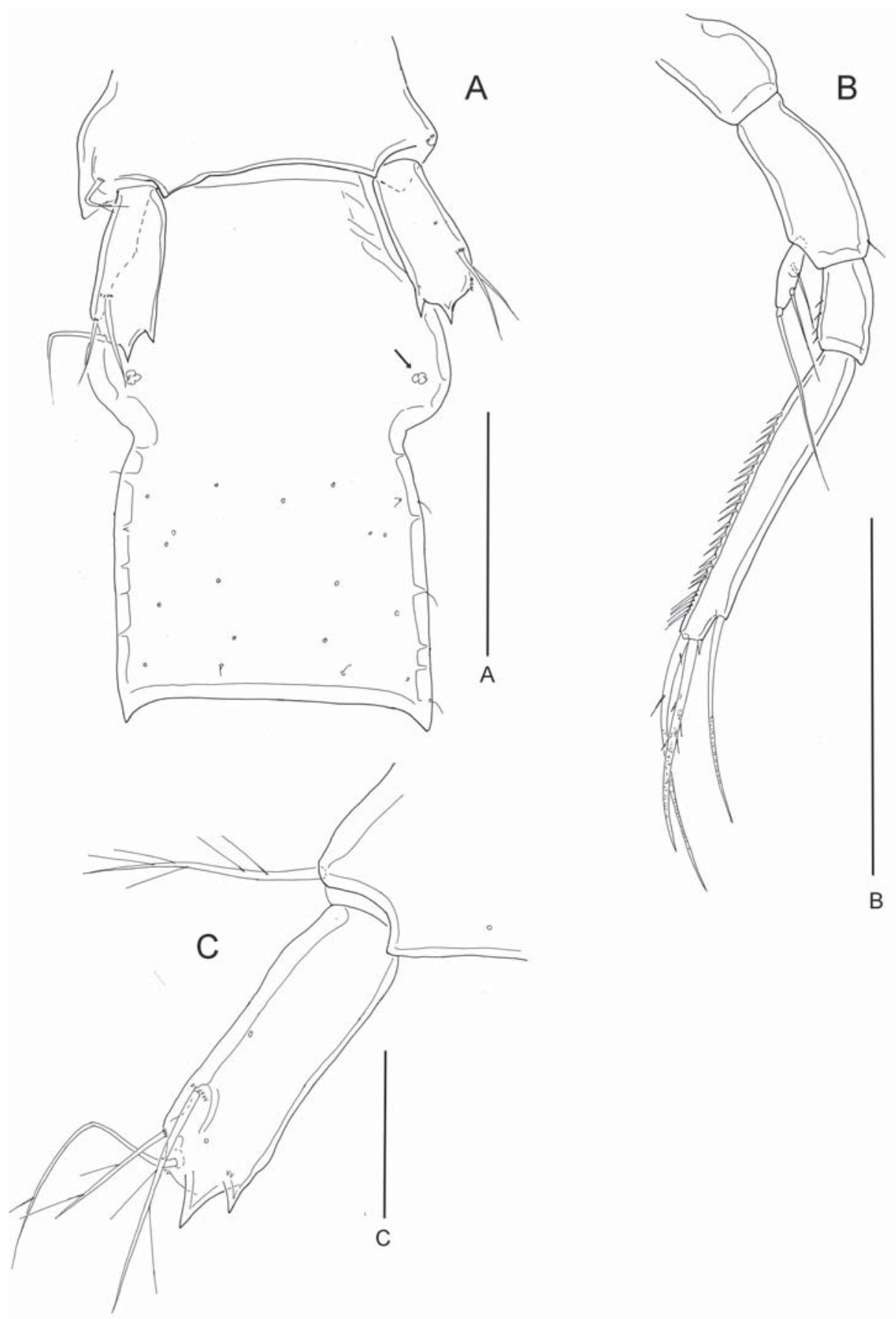

Fig. 3. Artogordion ridgeus gen. et sp.n., holotype female. A — somite with legs 5 and genital double-somite, ventral, copulatory opening arrowed; B - antenna; C - left leg 5. Scale bars: $0.3 \mathrm{~mm}$.

Рис. 3. Artogordion ridgeus gen. et sp.n., голотип, самка. А - сегмент с ногами 5 и двойной генитальный сегмент, вид снизу, половое отверстие отмечено стрелкой; В - антенна; С - левая нога 5. Масштабный отрезок: 0,3 мм. 


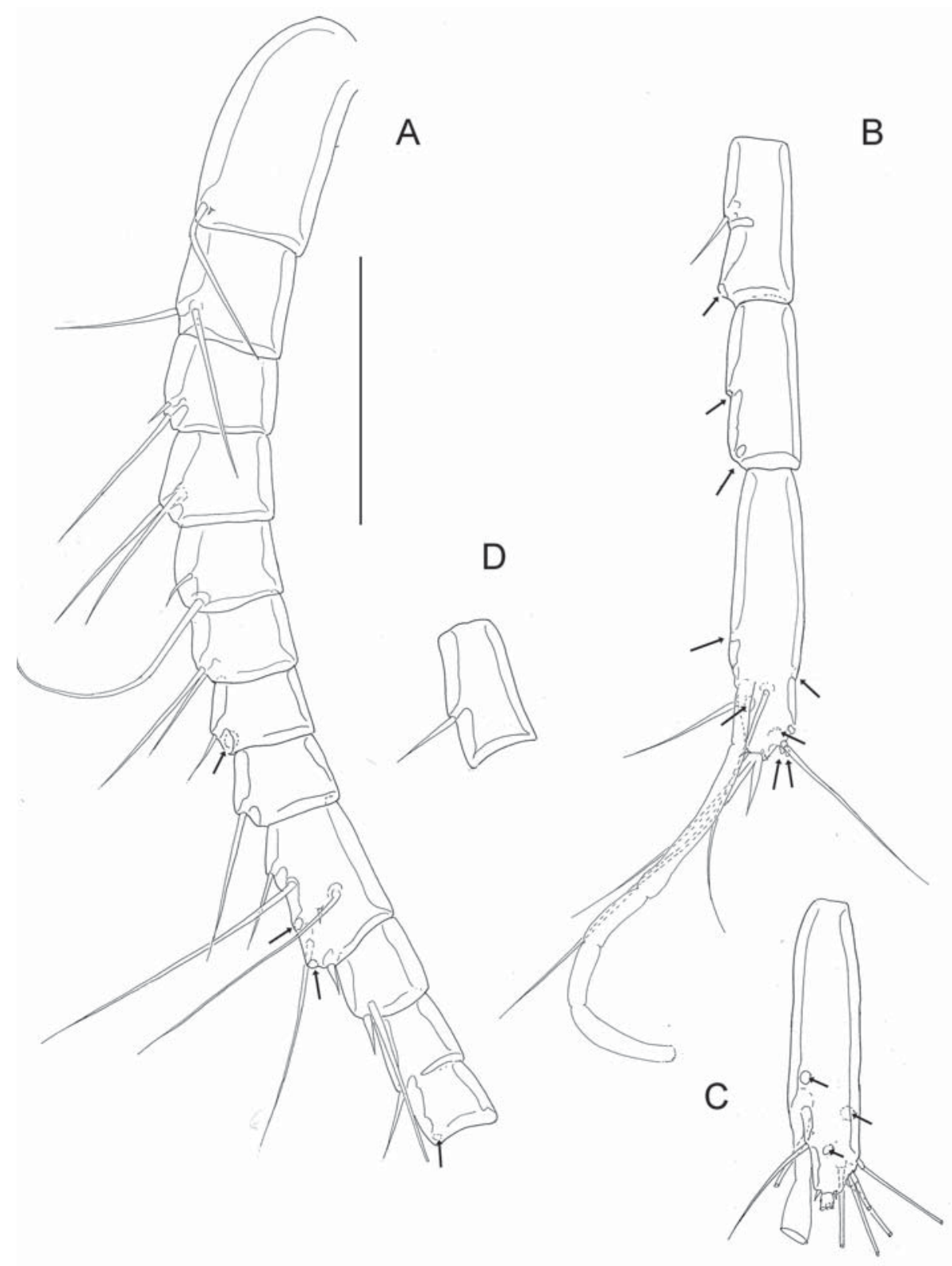

Fig. 4. Artogordion ridgeus gen. et sp.n., holotype female, antennule. A - proximal part, segments 1-11, ventral; B - distal part, segments 13-14, ventral; C - distal segment, ventral; D - segment 11, dorsal. Missing setae arrowed. Scale bar: $0.2 \mathrm{~mm}$.

Рис. 4. Artogordion ridgeus gen. et sp.n., голотип, самка, антеннулы. А - проксимальная часть, членики 1-11, вид снизу; В - дистальная часть, членики 13-14, вид снизу; С - дистальный членик, вид снизу; D - членик 11 , вид сверху. Положение утраченных щетинок отмечено стрелками. Масштабный отрезок: 0,2 мм. 


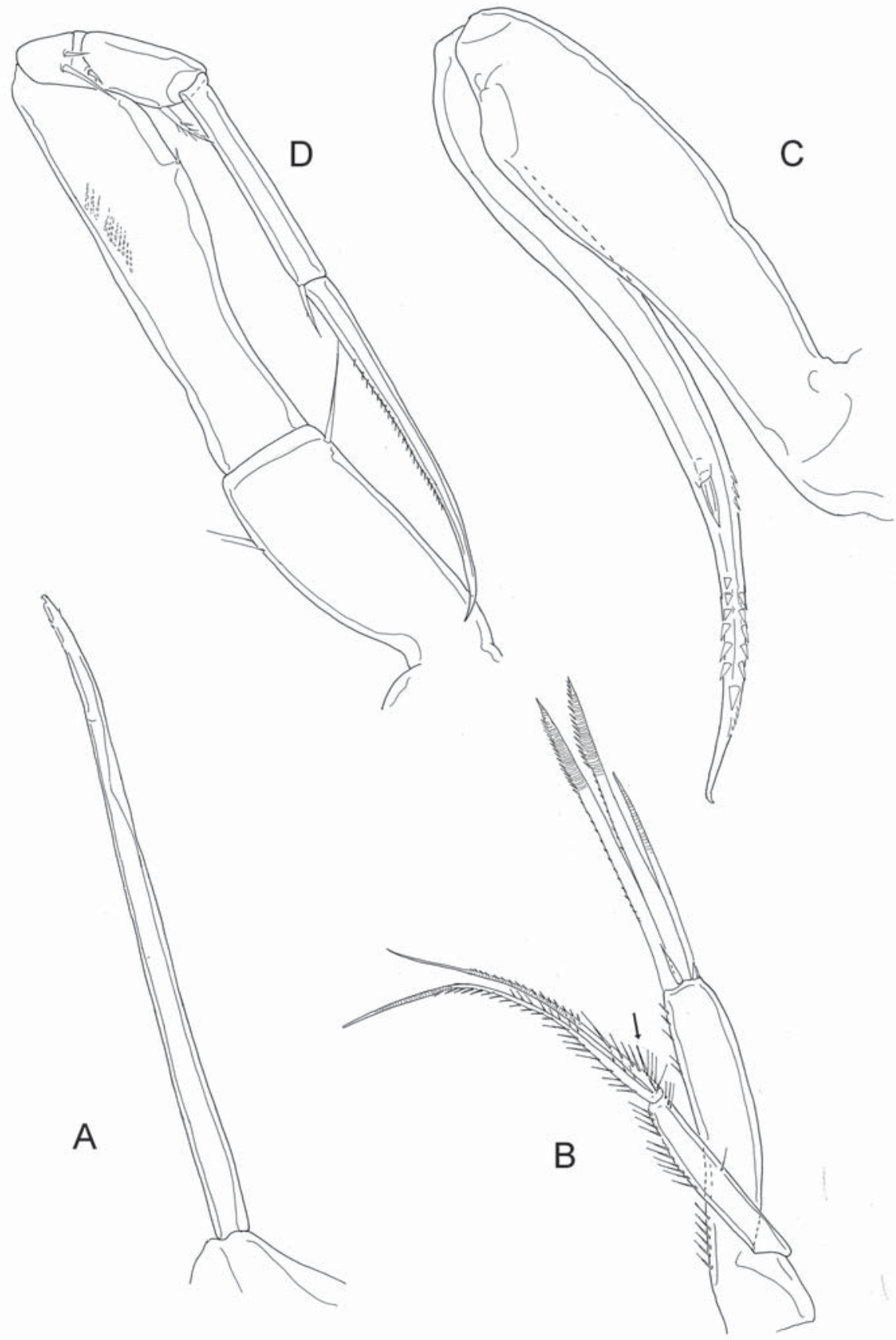

Fig. 5. Artogordion ridgeus gen. et sp.n., holotype female. A - mandible; B - maxillule, small seta arrowed; C - maxilla; D — right maxilliped, posterior. Scale bar: $0.3 \mathrm{~mm}$.

Рис. 5. Artogordion ridgeus gen. et sp.n., голотип, самка. А - мандибула; В - максиллула, короткая щетинка указана стрелкой; C - максилла; D - правый максиллипед, вид сзади. Масштабный отрезок: 0,3 мм. 


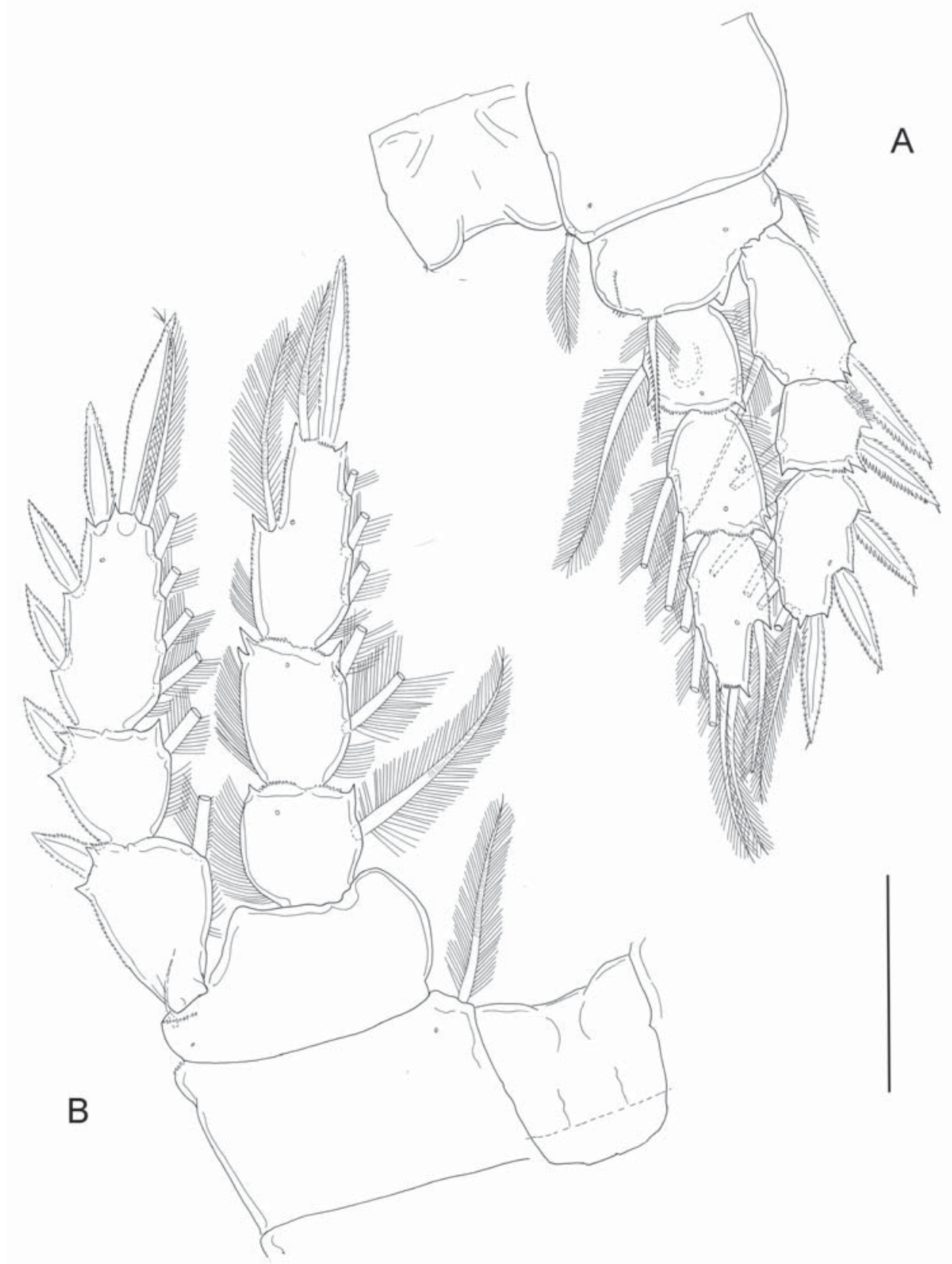

Fig. 6. Artogordion ridgeus gen. et sp.n., holotype female. A - left swimming leg 1 with intercoxal plate, anterior; B - left swimming leg 2 with intercoxal plate, anterior. Scale bar: $0.3 \mathrm{~mm}$.

Рис. 6. Artogordion ridgeus gen. et sp.n., голотип, самка. А - левая плавательная нога 1 с интеркоксальной пластинкой, вид спереди; В — левая плавательная нога 2 с интеркоксальной пластинкой, вид спереди. Масштабный отрезок: 0,3 мм. 


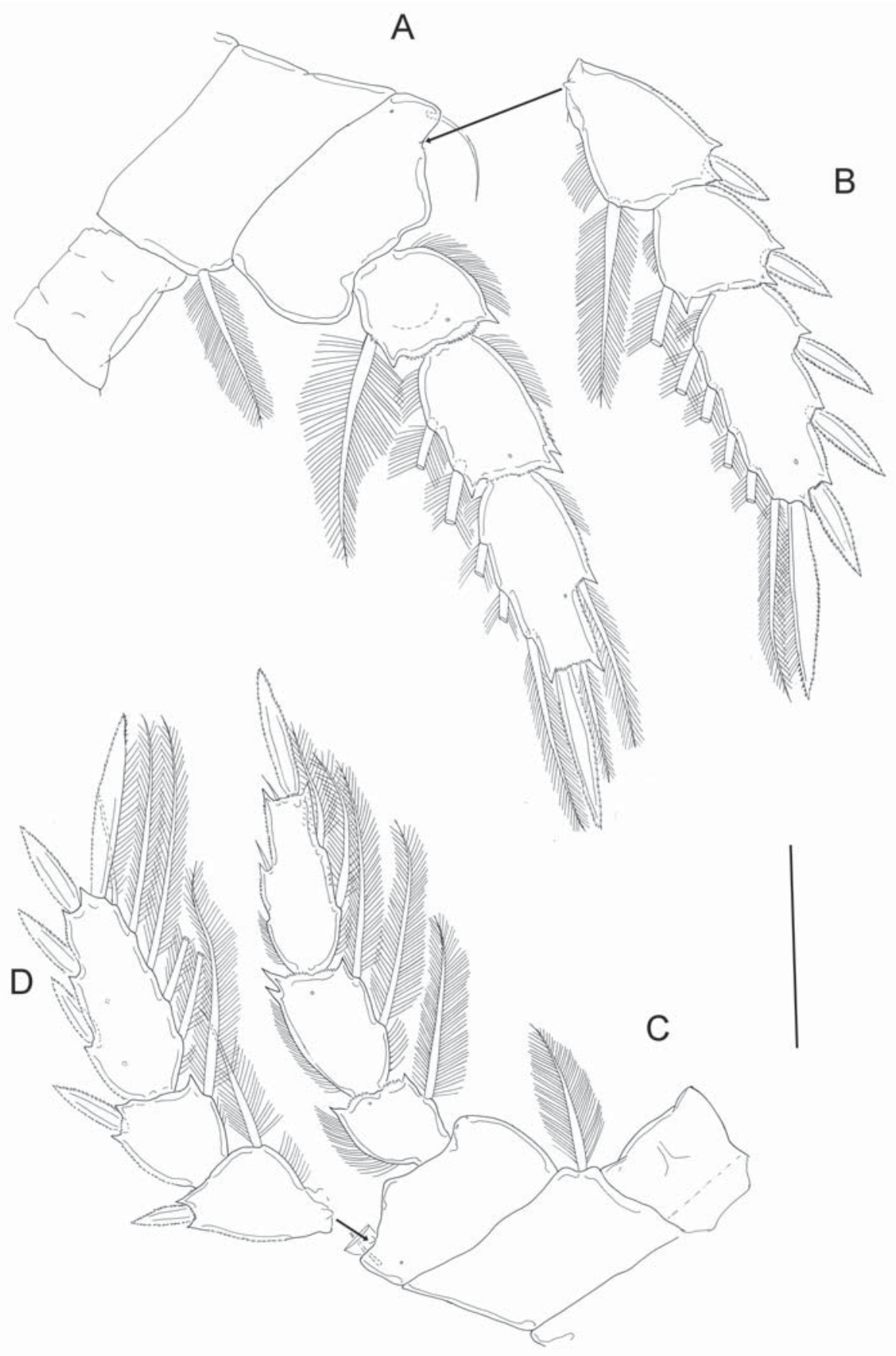

Fig. 7. Artogordion ridgeus gen. et sp.n., holotype female. A, B - left swimming leg 3 with intercoxal plate, anterior; C, D - left swimming leg 4 with intercoxal plate, anterior. Scale bar: $0.3 \mathrm{~mm}$.

Рис. 7. Artogordion ridgeus gen. et sp.n., голотип, самка. А, В - левая плавательная нога 3 с интеркоксальной пластинкой, вид спереди; C, D - левая плавательная нога 4 с интеркоксальной пластинкой, вид спереди. Масштабный отрезок: 0,3 мм. 


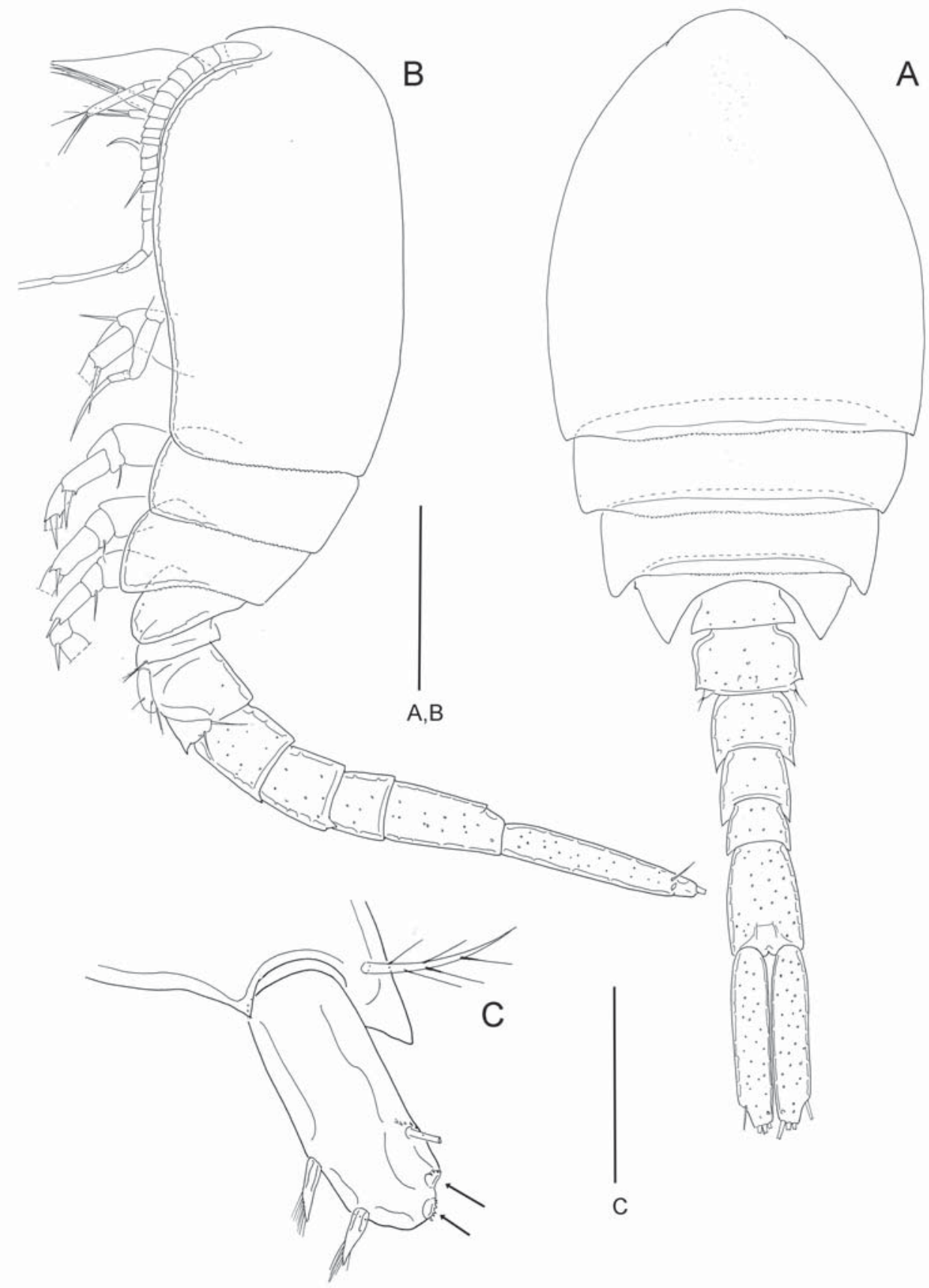

Fig. 8. Artogordion ridgeus gen. et sp.n., male. A - habitus, dorsal; B - habitus, lateral; C - right leg 5. Scale bars: A, B $-0.3 \mathrm{~mm}$; C $-0.05 \mathrm{~mm}$.

Рис. 8. Artogordion ridgeus gen. et sp.n., самец. А - общий вид сверху; В - общий вид сбоку; С правая нога 5. Масштабный отрезок: А, В - 0,3 мм; С-0,05 мм. 


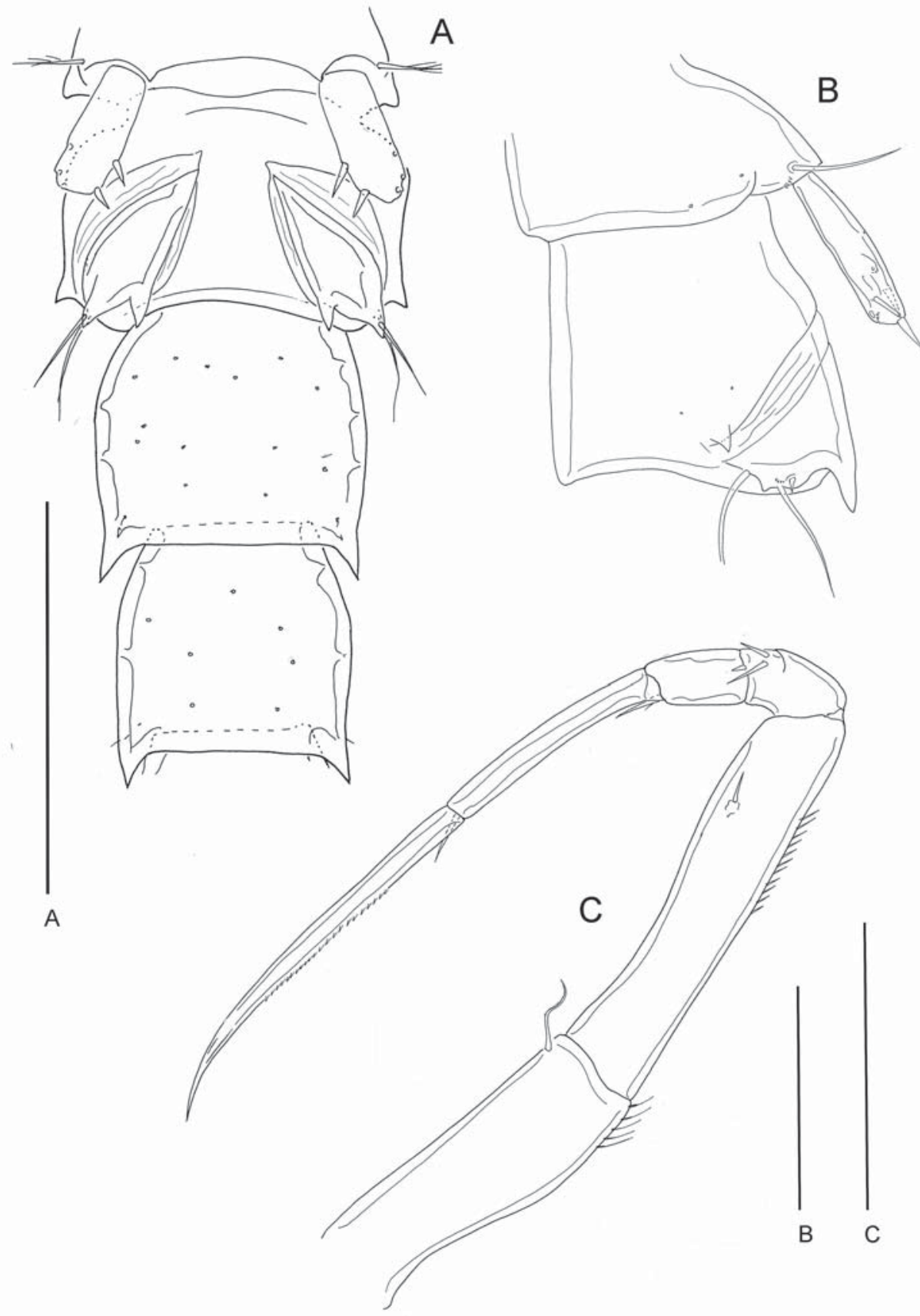

Fig. 9. Artogordion ridgeus gen. et sp.n., male. A - somite with legs 5, genital and two abdominal somites, ventral; B - somite with leg 5 and genital somite, lateral; C - maxilliped, posterior. Scale bars: A - 0.2 $\mathrm{mm} ; \mathrm{B}, \mathrm{C}-0.1 \mathrm{~mm}$.

Рис. 9. Artogordion ridgeus gen. et sp.n., самец. А - сегмент с 5-ми ногами, генитальный и два абдоминальных сегмента, вид снизу; В - сегмент с 5-ми ногами, генитальный и два абдоминальных сегмента, вид сбоку; С — максиллипед, вид сзади. Масштабный отрезок: А $-0,2$ мм; В, C - 0,1 мм. 


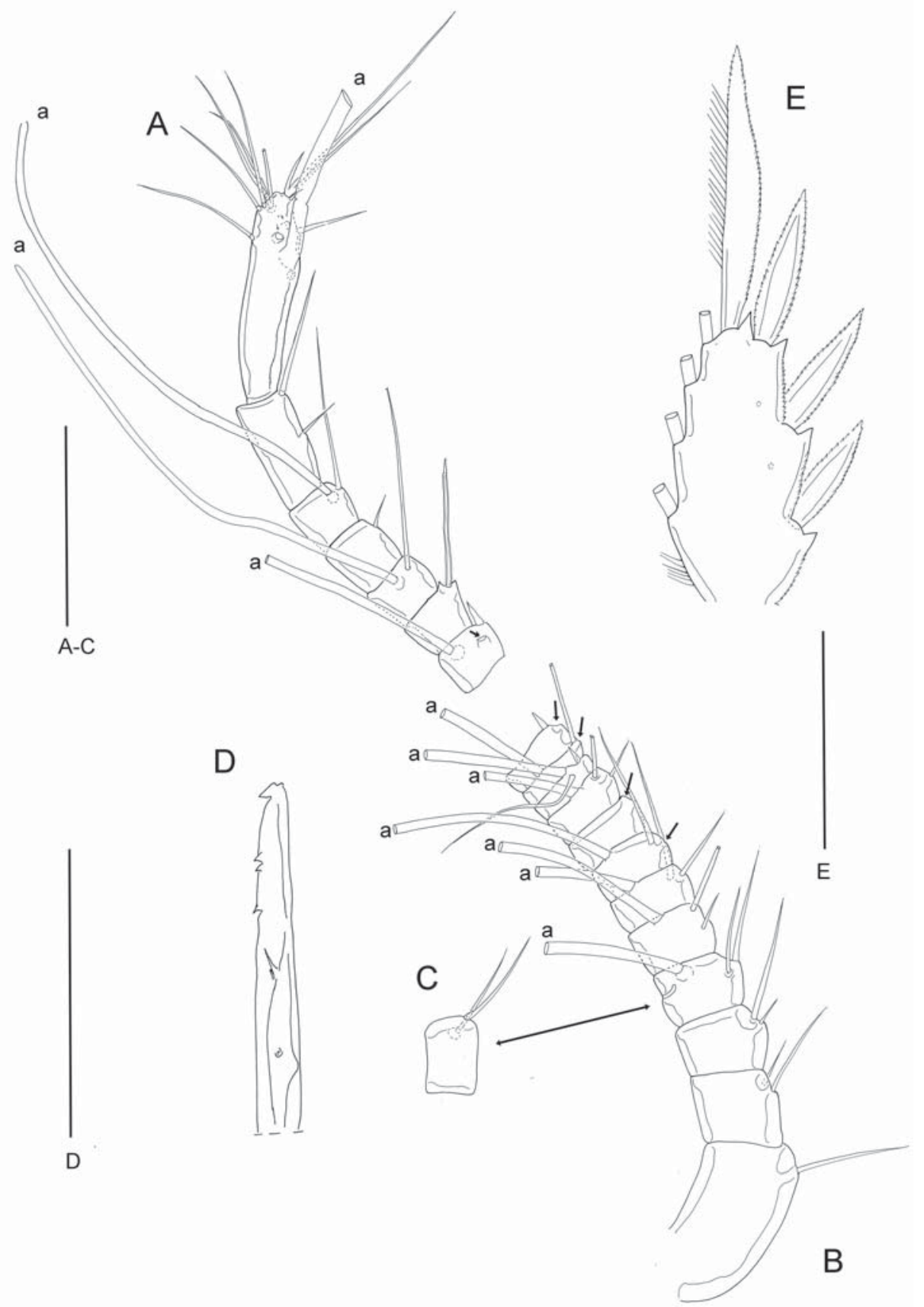

Fig. 10. Artogordion ridgeus gen. et sp.n., male. A, B - antennule, ventral view, a - aesthetasc, shown partly; $\mathrm{C}$ - segment 4 of antennules, dorsal view; D - tip of the mandibule; E - distal exopodal segment of leg 2, anterior. Missing setae arrowed. Scale bars: A-C, E $-0.1 \mathrm{~mm}$; D $-0.05 \mathrm{~mm}$.

Рис. 10. Artogordion ridgeus gen. et sp.n., самец. А, В - антеннула, вид снизу, а - эстетаск, показанный частично; C - 4-й членик антеннулы, вид сверху; D - кончик мандибулы; Е дистальный членик экзоподита 2-й ноги, вид спереди. Положение утраченных щетинок отмечено стрелками. Масштабный отрезок: $\mathrm{A}-\mathrm{C}, \mathrm{E}-0,1$ мм; D - 0,05 мм. 
segment and naked. Ornamentation of segments, setae and spines as shown in Fig. 6, 7.

Leg 5 (Fig. 3A, C) with protopod incorporated into somite, ventral, outer basal plumose seta displaced to lateral surface. Exopod rectangular, with 2 tooth-like processes on inner margin, bearing 3 setae of different lengths: 460 , 420 , and $250 \mu \mathrm{m}$.

Leg 6 (Fig. 2B, D) represented by 1 long seta $(170 \mu \mathrm{m})$ and 1 short spine and 1 minute spiniform process.

Colour of living specimen unknown.

Egg sacs not observed.

MALE. Body (Fig. 8A, B): total length excluding caudal setae: $1.85 \mathrm{~mm}$, greatest width 0.61 , greatest dorsoventral thickness $0.41 \mathrm{~mm}$. Prosome and urosome ornamented with sensilla and pores (shown for urosome). Urosome 6segmented consisting of fifth pedigerous somite, genital somite and 4 articulated abdominal somites. Genital somite 1.5 times as wide as long (Fig. 9A, B).

Antennule(Fig. 10A-C) 19-segmented; segmental fusion pattern and setation as follows (Roman numerals indicate ancestral segments number, following Huys, Boxshall, 1991 and Ivanenko, 1999; ae - aesthetasc, s - seta(e), sp - spiniform element): 1(I)-1s; 2(II)-2s, 3(III)-2s; 4(IV)-2s+ae; 5(V)-2s+ae; 6(VI)2s+ae; 7(VII)-2s+ae; 8(VIII)-1s; 9(IX-X)$2 \mathrm{~s}+\mathrm{ae} ; 10(\mathrm{XI})-1 \mathrm{~s}+\mathrm{sp}+\mathrm{ae} ; 11(\mathrm{XII})-2 \mathrm{~s}+\mathrm{ae} ; 12$ (XIII)-1s+sp; 13(XIV)-1s+sp+ae; 14(XV)-1s; 15(XVI)-1s+ae; 16(XVII)-1s; 17(XVIII)1s+ae; 18(XIX-XX)-2s; 19 (XXI-XXVIII)$13 \mathrm{~s}+$ ae. Segment 19 with three terminal setae fused at base. Segment 4 with small suture on surface but without complete division.

Antenna, mandible (Fig. 10D), maxillule, maxilla and maxilliped (Fig. 9C) as in female.

Formula of armature of swimming legs 1-4 similar to female except for distal exopodal segment of leg 2 (Fig. 10E) with 4 setae, not 5 .

Leg 5 (Figs 8C, 9A, B) with protopod incorporated into somite, ventral, outer basal plumose seta displace to lateral surface. Exopod with 3 setae and 2 spines on inner margin.

Leg 6 (Fig. 9A, B) represented by genital flap bearing 2 posterior outer setae, one spini- form element, and strong spiniform process on inner posterior margin.

ETYMOLOGY. The species name ridgeus is derived from the word "ridge" referring to the locality. Gender masculine.

ECOLOGICAL COMMENTS. Whether the mode of life of Artogordion ridgeus gen. et sp.n. is symbiotic or free living is unknown as for most other family members. Some of the artotrogid species have been found associated with sponges, corals, zoanthinarians, bryozoans, and ascidians (Boxshall, Halsey, 2004, Johnsson, Neves 2005, Kim, 2009). The type of feeding apparatus (pointed oral cone and styletlike element of mandible) indicates that the copepod feeds on tissues of one or more invertebrate hosts. A. ridgeus gen. et sp.n. was found among other copepods consisting mainly of harpacticoid copepods of the genus Tisbe Lilljeborg, 1853 which are common in shallow waters and have recently been reported in deep water hydrothermal vent fields and cold seeps (Ivanenko et al., 2011, Cuvelier et al., 2014). Other copepods of the order Siphonostomatoida found in the samples included Bathygordion cliffus Ivanenko, Arbizu, 2018 belonging to the family Ecbathyriontidae Humes, 1987 specific to deep sea hydrothermal vents of the eastern Pacific (Ivanenko, Arbizu, 2018).

\section{Discussion}

The most striking characteristics of Artogordion gen.n. are: (1) the 14-segmented antennules without any segmental fusion proximal to segment 9 and an aesthetasc on the apical segment in the female and the 19-segmented with 11 aesthetascs in the male; (2) the antennary second endopodal segment is almost four times longer than the first; (3) the absence of the mandibular palp; (4) the greater length of the inner lobe relative to the outer lobe of the maxillule, bearing five setae on the inner lobe and three setae on the outer; (5) the 5-segmented maxilliped with an armature formula of $1,1,3,1,1+$ claw; (6) the leg 5 exopod with three setae in both sexes together with two tooth-like processes in female or two spines in male on the 
inner margin; and (7) caudal ramus long, almost 6 times longer than wide, bearing 7 setae.

The new genus retains many plesiomorphic characters shared with Asterocheridae such as the absence of segmental fusion proximal to the ninth segment in the antennules of females and the morphology and armature of both the maxillule and maxilliped, and seems to be intermediate between the Artotrogidae and Asterocheridae. However the absence of the mandibular palp and the presence of the aesthetasc on the apical segment of the antennules clearly place this genus in the family Artotrogidae (Eiselt, 1961; Boxshall, Halsey, 2004). The presumed derived features of Artogordion gen.n. are the elongate caudal ramus and distal endopodal segment of antenna, and spiniform process on the genital flap of the male.

The family Artotrogidae is composed by 21 genera (Walter, Boxshall, 2018) which can be distinguished, among other characteristics, by the leg 4 morphology ranging from entirely absent such in Artotrogus Boeck, 1859, Glyptotrogus McKinnon, 1988 and Tardotrogus Eiselt, 1961; reduced to a stump as in Pseudotrogus Eiselt, 1961; with the endopod absent in Ascidipontius Kim, 1996, Crytopontius Giesbrecht, 1899, Dyspontius Thorell, 1859, Pteropontius Giesbrecht, 1895, Pulicitrogus Kim, 1998, and Sewellopontius Ummerkutty, 1966; with only two endopodal segments as in Arctopontius Sars, 1915 and Metapontius Hansen, 1923; to the typical biramous leg 4 with 3segmented rami present as in Artogordion gen.n. Nine artotrogid genera share this characteristic with the new genus: Abyssopontius Stock, 1985; Antarctopontius Eiselt, 1965; Bradypontius Giesbrecht, 1895; Cribropontius Giesbrecht, 1899; Glannapontius Holmes, 1998; Myzopontius Giesbrecht, 1895; Neobradypontius Eiselt, 1961; Neopontius T. Scott, 1898 and Sestropontius Giesbrecht, 1899. Most of these genera (Abyssopontius, Antarctopontius, Bradypontius, Cribropontius, and Neobradypontius) have the body moderately transformed by extreme flattening of the prosome and occasionally their urosome is reduced. Four genera, Glannapontius, Myzopontius, Neopontius, Sestropontius together with the new genus, Artogordion, show a typical cyclopiform body with an oval prosome and somewhat cylindrical urosome.

Artogordion gen.n. is easily distinguishable from Glannapontius Holmes, 1998 having the aesthetasc on the penultimate segment of the antennule, the exopod of antenna represented by two setae, and by the presence of two well developed terminal elements on the second endopodal segment of the antenna (Holmes, 1998). Furthermore, Glannapontius is the only genus in the group of five genera with five setae on the free segment of the leg 5 .

The leg 5 armature serves to separate $A r$ togordion gen.n. from Myzopontius, Neopontius and Sestropontius since the new genus is the only with two tooth-like processes (in female) or two spines (in male) on the inner margin of the free segment in addition to three setae in both sexes. Myzopontius and Sestropontius bear three setae on the exopod and Neopontius has three setae plus one tooth-like process on the inner margin (Giesbrecht, 1899, Johnsson, Rocha, 2002, Stock, 1965, Conradi, 2014).

The typical artotrogid female antennule is 8 to 14-segmented with segmental fusion on segment two or three (Boxshall, Halsey, 2004). However two genera, Abyssopontius and Metapontius, have segments I to VIII free (Hansen, 1923; Stock, 1985). Although type species Sestropontius bullifer Giesbrecht, 1899, like Myzopontius and Neopontius, have a segmental fusion on segments II to IV or II to V to form the compound second segment the only congenus $S$. mackinnoni Johnsson et Rocha, 2002 with long oral cone retains segments I to VIII free (Johnsson, Rocha, 2002). The antennule of Artogordion gen.n. is similar to that of S. mackinnoni, both of them are 14-segmented, with segments 1 to 8 free, segment 9 compound (IX-XIII), segment 10 free, segments 11 to 13 double (formed by two ancestral segments each) and terminal segment 14 composed by 8 ancestral segments. These antennules are different from those of many Asterocheridae by the fusion of segments and presence of the aesthetasc on the distal segment (Ivanenko, 1999; Ivanenko, Smurov, 1997; Defaye, 2004; Ivanenko, Ferrari, 2003). 
The maxillule of the new genus, Artogordion gen.n., resembles the typical maxillule of the Asterocheridae family, with the inner lobe armed with four or five setae and the outer lobe shorter than the inner bearing one to four setae (Ivanenko, Smurov, 1997). The maxillule of Artogordion displays an inner lobe that is longer than the outer lobe and bears five terminal setae, with the articulating lobe bearing three terminal setae. In contrast, Myzopontius has a maxillule with a conical inner lobe slightly shorter than the rectangular outer lobe: the inner lobe carries one seta and the outer, two setae (Giesbrecht, 1895, Sars, 1915). In Neopontius the inner lobe of the maxillule has four terminal setae and it is slightly longer than the outer lobe which bears two setae (T. Scott, 1898, Sars, 1915). The maxillule of Sestropontius also has the inner lobe longer than the outer, but with only two setae on each lobe (Giesbrecht, 1899, Johnsson, Rocha, 2002, Stock, 1965; Conradi, 2014).

The retention of many pleisomorphic features mentioned above together with the preservation of eleven aesthetascs on the antennule of the male and the presence of seven caudal setae, suggest that the ancestor of new genus may have diverged early from the main artotrogid lineage and is closest to the genus Myzopontius.

\section{Acknowledgements}

We are grateful to Janet Voight conducted field work, Pedro Martinez Arbizu for providing sorted copepods, Frank Ferrari, Geoff Boxshall and Maria Schreider for commenting draft of the manuscript. Microscopic work was conducted at Deutsches Zentrum für Marine Biodiversitätsforschung of Senckenberg Research Institute (Wilhelmshaven, Germany). Illustrative work and paper preparation were conducted with support of the Russian Foundation for Basic Research (grants 15-54-78061 and 1804-01192, respectively).

\section{References}

Boxshall G.A. 1998. Host specificity in copepod parasites of the deep-sea fishes // Journal of Marine Systems. Vol.15. P.215-223.
Boxshall G.A., Halsey S.H. 2004. An introduction to the copepod diversity. London: The Ray Society. 966 p.

Conradi M. 2014. Three artotrogids (Crustacea: Copepoda: Siphonostomatoida) from the Ross Sea, Antarctica // Polar Research. Vol.33. P.1-10.

Cuvelier D., Beesau J., Ivanenko V.N., Zeppilli D., Sarradin P.-M., Sarrazin J. 2014. First insights into macroand meiofaunal colonisation patternson paired wood/ slate substrata at Atlantic deep-sea hydrothermal vents // Deep-Sea Research Part I: Oceanographic Research Papers. Vol.87. P.70-81.

Eiselt J. 1961. Neubeschreibungen und Revision siphonostomer Cyclopoiden (Copepoda, Crust.) von der südlichen Hemisphäre nebst Bemerkungen über die Familie Artotrogidae Brady 1880 // Denkschriften der Kaiserlichen Akademie der Wissenschaften. Mathematisch-Naturwissenschaftliche Classe (Abt. 1). Bd.170. S.315-366.

Ferrari F.D., Ivanenko V.N. 2008. Identity of the protopodal segments and the ramus of maxilla 2 of copepods (Crustacea) // Crustaceana. Vol.81. P.823-835.

Giesbrecht W. 1895. The subfamilies, genera, and species of the copepod family Ascomyzontidae, Thorell: diagnosis, synonymy and distribution // Annals and Magazine of Natural History. Vol.6. P.173-186.

Giesbrecht W. 1899. Die Asterocheriden des Golfes von Neapel und der angrezender Meeres-Abschnitte // Fauna und Flora des Golfes von Neapel. Bd.25. S.1217.

Gollner S., Ivanenko V.N., Arbizu P.M., Bright M. 2010. Advances in taxonomy, ecology, and biogeography of Dirivultidae (Copepoda) associated with chemosynthetic environments in the deep Sea // PLoS ONE. 5. e9801.

Hansen H.J. 1923. Crustacea Copepoda. II. Copepoda parasita and hemiparasita // The Danish Ingolf-Expedition. Vol.3. P.1-92.

Holmes J.M.C. 1998. Phenetic relationships among some free-living siphonostomatoid copepods from southwest Ireland, and the description of Glannapontius maculatus gen. et sp. nov. // Journal of Marine Systems. Vol.15. P.229-241.

Humes A.G. 1974. New cyclopoid copepods associated with an abyssal holothurian in the eastern North Atlantic // Journal of Natural History. Vol.8. P.101117.

Humes A.G. 1987. Copepoda from deep-sea hydrothermal vents // Bulletin of Marine Science. Vol.41. P.645788.

Humes A.G. 1988a. Hyalopontius boxshalli, new species (Copepoda: Siphonostomatoida), from a deep-sea hydrothermal vent at the Galapagos Rift // Proceedings of the Biological Society of Washington. Vol.101. P.825-831.

Humes A.G. 1988b. Bythocheres prominulus, a new genus and species (Copepoda: Siphonostomatoida) from deep-water cold seeps at the West Florida escarpment // Proceedings of the Biological Society of Washington. Vol.101. P.568-575.

Huys R., Boxshall G.A. 1991. Copepod evolution. London: The Ray Society. 486 p. 
Ivanenko V.N. 1998. [Deep-sea hydrothermal vent Copepoda (Siphonostomatoida: Dirivultidae) in plankton over the Mid-Atlantic Ridge $\left(29^{\circ} \mathrm{N}\right)$, morphology of their first copepodid stage] // Zoologicheskii Zhurnal. Vol.77. P.1249-1256 [in Russian, with English summary].

Ivanenko V.N. 1999. Comparative analysis of the asterocherid antennules (Copepoda: Siphonostomatoida) symbionts of marine invertebrates // F.R. Schram, J.C. von Vaupel Klein (eds.). Proceedings of the Fourth International Crustacean Congress. London: CRC Press. P.207-216.

Ivanenko V.N., Arbizu P.M. 2018. A new deep-sea genus and species of the family Ecbathyriontidae (Copepoda: Siphonostomatoida) from the Gorda Ridge (North Pacific Ocean) // Marine Biodiversity. Vol.48. P.195201.

Ivanenko V.N., Arbizu P.M., Stecher J. 2007. Lecithotrophic nauplius of the family Dirivultidae (Copepoda; Siphonostomatoida) hatched on board over the Mid-Atlantic Ridge ( $\left.5^{\circ} \mathrm{S}\right) / /$ Marine Ecology. Vol.28. P.49-53.

Ivanenko V.N., Corgosinho P.H.C., Ferrari F., Sarradin P.M., Sarrazin J. 2011. Microhabitat distribution of Smacigastes micheli (Copepoda: Harpacticoida: Tegastidae) from deep-sea hydrothermal vents at the Mid-Atlantic Ridge, $37^{\circ} \mathrm{N}$ (Lucky Strike), with a morphological description of its nauplius // Marine Ecology. Vol.33. P.246-256.

Ivanenko V.N., Defaye D. 2004. A new genus and species of the family Asterocheridae (Copepoda: Siphonostomatoida) from the East Equatorial Atlantic (Angola margin) // Crustaceana. Vol.77. P.1131-1144.

Ivanenko V.N., Defaye D., Segonzac M., Khripounoff A., Sarrazin J., Ferrari F.D. 2011. A new species of Exrima, synonymy of four species of Aphotopontius, Stygiopontius and Rhogobius, and record of first copepodid stage of Dirivultidae (Copepoda: Siphonostomatoida) from deep-sea hydrothermal vents of the East Pacific Rise $\left(13^{\circ} \mathrm{N}\right) / /$ Journal of the Marine Biological Association of the United Kingdom. Vol.91. P.1547-1559.

Ivanenko V.N., Ferrari F.D. 2003. Redescription of adults and description of copepodid development of Dermatomyzon nigripes (Brady \& Robertson, 1876) and of Asterocheres lilljeborgi Boeck, 1859 (Copepoda: Siphonostomatoida: Asterocheridae) // Proceeding of the Biological Society of Washington. Vol.116. P.661691.

Ivanenko V.N., Smurov A.V. 1997. Asterocheres flustrae n. sp. (Copepoda: Siphonostomatoida: Asterocheridae) associated with Flustra foliacea L. (Bryozoa) from the White Sea // Systematic Parasitology. Vol.38. P.111-130.

Johnsson R., Neves E.G. 2005. A revision of Metapontius (Siphonostomatoida: Artotrogidae) with the description of a new species associated with an octocoral from Eniwetok Atoll, Marshall Islands (USA) // Zootaxa. Vol.1035. P.51-59.

Johnsson R., Rocha C.E.F. 2002. Five artotrogids (Crustacea: Copepoda: Siphonostomatoida) from Eastern Antarctica // Memoirs of the Museum of Victoria. Vol.59. P.439-455.

Kakui K. 2016. Descriptions of two new species of Rhizorhina Hansen, 1892 (Copepoda: Siphonostomatoida: Nicothoidae) parasitic on tanaidacean crustaceans, with a note on their phylogenetic position // Systematic Parasitology. Vol.93. P.57-68.

Kim I.-H. 2009. Artotrogus gordoni n. sp. (Copepoda: Siphonostomatoida: Artotrogidae) associated with the Bryozoan Schizomittina cinctipora (Hincks) from New Zealand // The Korean Journal of Zoology. Vol.25. P.5-9.

Mahatma R., Arbizu P.M., Ivanenko V.N. 2008. A new genus and species of Brychiopontiidae Humes, 1974 (Crustacea: Copepoda: Siphonostomatoida) associated with an abyssal holothurian in the Northeast Pacific Nodule Province // Zootaxa. Vol.1866. P.290-302.

Sars G.O. 1915. Copepoda Cyclopoida // An account of the Crustacea of Norway with short descriptions and figures of all the species. Vol.6. P.81-140.

Scott T. 1898. Some additions to the invertebrate fauna of Loch Fyne // Annual report of the Fishery Board for Scotland. Vol.16. P.261-282.

Stock J.H. 1965. Copépodes associés aux invertébres des côtes du Rousillon // Crustaceana. Vol.1. P.218-257.

Stock J.H. 1985. Un Copépode Siphonostomatoide abyssal nouveau del'Océan Indien // Hydrobiologia. Vol.126. P.129-134.

Voight J.R. 2005. First report of the enigmatic echinoderm Xyloplax from the North Pacific // The Biological bulletin. Vol.208. P.77-80.

Voight J.R. 2007. Experimental deep-sea deployments reveal diverse Northeast Pacific wood-boring bivalves of Xylophagainae (Myoida: Pholadidae) // Journal of Molluscan Studies. Vol.73. P.377-391.

Walter T.C., Boxshall G. 2018. World of Copepods database. Artotrogidae Brady, 1880 // Accessed through: World Register of Marine Species at: http://www. marinespecies.org/aphia.php? $\mathrm{p}=$ taxdetails \&id= 135510 on $2018-07-06$

Responsible editor A.A. Kotov 